\section{Pacific Northwest}

National Laboratory

Operated by Battelle for the

U.S. Department of Energy

\title{
Addendum to the 200 West Area Dust Mitigation Strategies: Treatment of the Dust Source Area
}

J. Becker

M. Sackschewsky

May 2001

Prepared for the U.S. Department of Energy under Contract DE-AC06-76RL01830 


\title{
DISCLAIMER
}

This report was prepared as an account of work sponsored by an agency of the United States Government. Neither the United States Government nor any agency thereof, nor Battelle Memorial Institute, nor any of their employees, makes any warranty, express or implied, or assumes any legal liability or responsibility for the accuracy, completeness, or usefulness of any information, apparatus, product, or process disclosed, or represents that its use would not infringe privately owned rights. Reference herein to any specific commercial product, process, or service by trade name, trademark, manufacturer, or otherwise does not necessarily constitute or imply its endorsement, recommendation, or favoring by the United States Government or any agency thereof, or Battelle Memorial Institute. The views and opinions of authors expressed herein do not necessarily state or reflect those of the United States Government or any agency thereof.

\author{
PACIFIC NORTHWEST NATIONAL LABORATORY \\ operated by \\ BATTELLE \\ for the \\ UNITED STATES DEPARTMENT OF ENERGY \\ under Contract DE-AC06-76RL01830
}

Printed in the United States of America

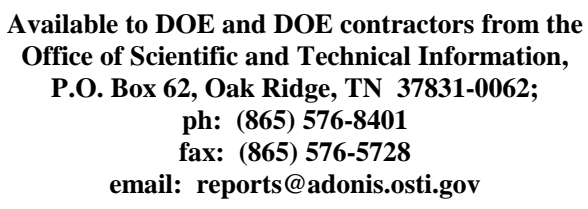

Available to the public from the National Technical Information Service, U.S. Department of Commerce, 5285 Port Royal Rd., Springfield, VA 22161 ph: (800) 553-6847 fax: $(703) 605-6900$

email: orders@ntis.fedworld.gov

online ordering: http://www.ntis.gov/ordering.htm 


\title{
ADDENDUM TO THE \\ 200 WEST AREA \\ DUST MITIGATION STRATEGIES:
}

\section{TREATMENT OF THE DUST SOURCE AREA}

\author{
PREPARED FOR \\ CH2M Hill Hanford Group
}

May 14, 2001

BY

J.M. BECKER AND M.R. SACKSCHEWSKY

PACIFIC NORTHWEST NATIONAL LABORATORY 


\section{Source Area}

The source area for the blowing dust and sand was initially estimated at approximately 5,000-6,000 acres. This area begins just within the eastern border of the Arid Lands Ecology (ALE) Reserve and extends northward and eastward to the southwest portion of the 200 West Area. (A geo-referenced map that would permit a more accurate calculation of the source area is currently unavailable and is being acquired).

Since then, the source area has been hand drawn via ocular reconnaissance from a vehicle (Figure 1). This new source area is estimated at approximately 5,000 acres (Figure 1). However, we are considering only 4,000 of the 5,000 acres to be an important source of airborne dust and sand at the receptor location (Figure 1). This is based on the direction of the four wind events that were of sufficient strength (sustained [at least 1 hour] winds over $25 \mathrm{mph}$ ) to cause early work release (March 13 and 19, and April 1 and 30 of 2001) (Marquardt, personal communication May 15, 2001). These winds, as experienced at the receptor location (Figure1), originated from $210^{\circ}$ to $330^{\circ}$ (Marquardt, personal communication May 15, 2001). Consequently, the approximately 1,000 acres located south of the 200 West Area are considered to be a relatively unimportant source of blowing dust and sand.

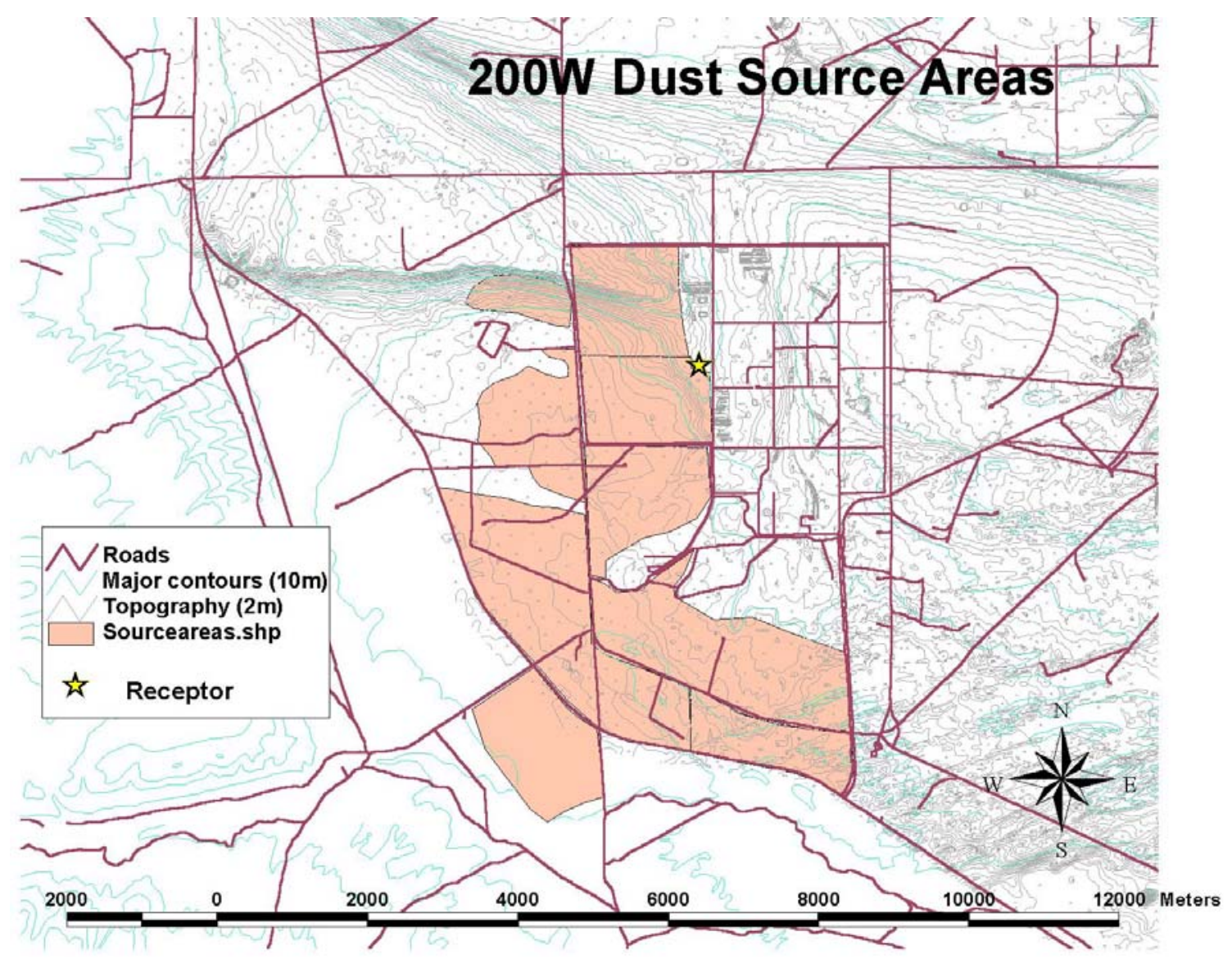

Figure 1. Source area (hand drawn via ocular reconnaissance from a vehicle) for blowing dust and sand. 


\section{Complete Short-Term Stabilization of the Source Area (Summer to Fall 2001)}

Complete stabilization of blowing dust and sand for the summer and fall of 2001 would require application of a soil fixative to the surface of the entire source area. Application methods, associated time and water requirements, and costs that were provided in writing by a local supplier of this service (Wildlands Inc., Richland, WA) for coverage of the entire source area with Soil Master (an acrylic polymer) are found in Table 1. Wildlands Inc. will guarantee dust suppression for up to 6 months following application. Wildlands Inc. has also verbally agreed to re-apply Soil Master, at no additional charge, to any areas that destabilize during this time. Wildlands Inc. could begin work as early as one to two weeks from date of notification.

Table 1. Application methods, associated time and water requirements, and costs for treating 6,000 acres with Soil Master (Wildlands Inc.). The cost per acre associated with the truck application method remain the same for the new source area of approximately 4,000 acres, for a total cost of $\$ 1,252,000$.

\begin{tabular}{|c|c|c|c|c|}
\hline $\begin{array}{l}\text { Application } \\
\text { Method }\end{array}$ & $\begin{array}{l}\text { Total Time } \\
\text { Required (d) }\end{array}$ & $\begin{array}{c}\text { Total Water } \\
\text { Required } \\
\text { (gal/day) }\end{array}$ & $\begin{array}{c}\text { Cost (\$) per } \\
\text { Acre }^{\mathrm{a}}\end{array}$ & $\begin{array}{c}\text { Total Cost } \\
(\$)^{\mathbf{a}}\end{array}$ \\
\hline $\begin{array}{l}\text { Fixed Wing } \\
\text { Aircraft }\end{array}$ & 70 & 171,428 & 914.22 & $5,485,320$ \\
\hline Helicopter & 40 & 300,000 & 777.78 & $4,666,680$ \\
\hline Truck & 45 & 240,000 & 331.00 & $1,986,000$ \\
\hline
\end{tabular}

${ }^{a}$ Cost of dye used to tint the Soil Master-water slurry (for the purpose of tracking portions already covered during application) are not included and are minimal. The dye degrades within a few days following application of the Soil Master-water slurry.

The local supplier (America West Environmental Supplies, Inc., Pasco, WA) and manufacturer (Midwest Industrial Supply, Inc., Canton, OH) of Soil Sement were contacted. The 6,000-acre area could be stabilized with this product using trucks for a total of approximately $\$ 2,000,000$ to $\$ 2,500,000$. This verbal estimate did not include total time or water requirements; however, Midwest Industrial Supply, Inc. indicated that these would be similar to those found in Table 1. Midwest Industrial Supply, Inc. indicated dust suppression should last at least 6 months, but did not offer a guarantee. The total cost for this application would be $\$ 1,200,00$ to $\$ 1,500,000$ (60\% of the price to treat 6,000 acreas) for the new source area of approximately 4,000 acres.

A local supplier of non-ionic polyacrylimides (PAMs) (AEM [Agricultural and Environmental Management] Inc., Tri-Cities, WA, headquartered in Woods Cross, UT) was contacted by Richard Roos (Duratek). This supplier proposed applying $75 \mathrm{lbs}$ of PAM and 1,200 lbs of natural wood fiber (mulch) per acre at a cost of $\$ 496.00 /$ acre (separate costs for application of PAM and hydromulch were not provided). This cost was based on the size of the source area being 3,000 acres. AEM would employ 2 teams with tractors and tow-behind hydromulchers and the work would take approximately 40 to 50 days to complete. If PAM were applied at 85 or $95 \mathrm{lbs} /$ acre, assuming the same mulch application rate, the costs would be $\$ 515.00$ and $\$ 531.00$, respectively. AEM indicated that PAM applied at $40 \mathrm{lbs} /$ acre would degrade within 6 months, and used this 
as a rationale for proposing application of $75 \mathrm{lbs} /$ acre or more. The supplier, however, did not guarantee dust suppression for 6 months.

The efficacy of applying mulch with a soil fixative is highly questionable under these circumstances. The purpose of mulch is primarily to retain moisture in order to facilitate germination and establishment of planted seeds. However, no plants should be seeded in the spring for the reasons cited below (see section on Long-Term Stabilization of the Entire Source Area [Fall 2001]). If mulch were to be applied with a soil fixative, it likely would absorb some or much of the fixative, reducing the amount of fixative available to penetrate into and bind the upper soil layer. This would likely reduce the effectiveness and longevity of the soil fixative at stabilizing the soil. In addition, a more weakly stabilized soil covered with mulch that would catch surface winds could be subject to peeling in high winds. This peeling process would serve to accelerate destabilization of the soil.

It should be noted that applying any soil fixative over the entire source area would not guarantee a reduction in dust concentration levels at the affected facilities to pre-fire conditions. However, it would likely provide the maximum reduction possible in dust levels given current site conditions and available dust suppression practices.

Application of the soil fixative over the complete source area would begin on the ALE Reserve (this may require coordination and approval of the U.S. Fish and Wildlife Service) and move northward and eastward. In this manner, previously treated portions could not be covered by blowing dust and sand during application.

\section{Short-Term Stabilization of a Portion of the Source Area (Summer to Fall 2001)}

Partial cost reductions (from those cited in Table 1) and corresponding partial reductions in airborne dust may be achieved by applying soil fixative to only a portion of the source area. Reductions in dust concentrations were correlated by Dr. Van Ramsdell (PNNL atmospheric scientist) with two source areas (that could potentially be treated with soil fixative) as a function of distance upwind of the facilities in the northwesterly and southwesterly directions, as follows. 
The following general assumptions were made:

- the two dust source areas extend 2 miles $(3200 \mathrm{~m})$ upwind of the facilities in the northwesterly direction and 4 miles $(6400 \mathrm{~m})$ in the southwesterly direction, and these are horizontally homogeneous;

- the wind field is horizontally homogeneous (wind direction and speed are constant) and that the atmospheric stability is Pasquill-Gifford Class D (Stability class is a description of the turbulence in the atmosphere that causes dispersion. Stability class D occurs in a well mixed atmosphere, which is the case during high winds); and

- the two source areas could be approximated by a series of infinite line sources spaced at $1 \mathrm{~m}$ intervals from $0.5 \mathrm{~m}$ to $8000 \mathrm{~m}$.

For the first 25-meter wide band, it was assumed that the airborne concentration from each line source was equal to the concentration from a line source at $12.5 \mathrm{~m}$. Similar assumptions were made for 25 -meter wide bands to a distance of $100 \mathrm{~m}, 50 \mathrm{~m}$ bands from 100 to $1000 \mathrm{~m}, 100 \mathrm{~m}$ wide bands from $1000 \mathrm{~m}$ to $2000 \mathrm{~m}$, and $200 \mathrm{~m}$ bands from $2000 \mathrm{~m}$ to $8000 \mathrm{~m}$.

For the graphs in Figures 2 and 3, the total airborne concentrations were calculated as the sum of the concentrations from all line sources from $0.5 \mathrm{~m}$ to $3200 \mathrm{~m}$ (0 to $2 \mathrm{mi}$ ) and from 0.5 to $6400 \mathrm{~m} \mathrm{(4} \mathrm{mi),} \mathrm{respectively.} \mathrm{In} \mathrm{Figures} 2$ and 3, the horizontal axes represent the distance upwind from the facilities to which soil fixative could be applied. The vertical axes represent approximate reductions in airborne dust concentrations resulting from the soil stabilization. The air concentrations are calculated at 3 heights above ground, $1 \mathrm{~m}, 3 \mathrm{~m}$, and $5 \mathrm{~m}$ (the concentration at $3 \mathrm{~m}$ is expected to be $84 \%$ of that at $1 \mathrm{~m}$, and the concentration at $5 \mathrm{~m}$ is expected to be $74 \%$ of that at $3 \mathrm{~m}$ ). The height of interest is that which corresponds to where air enters the facilities. 


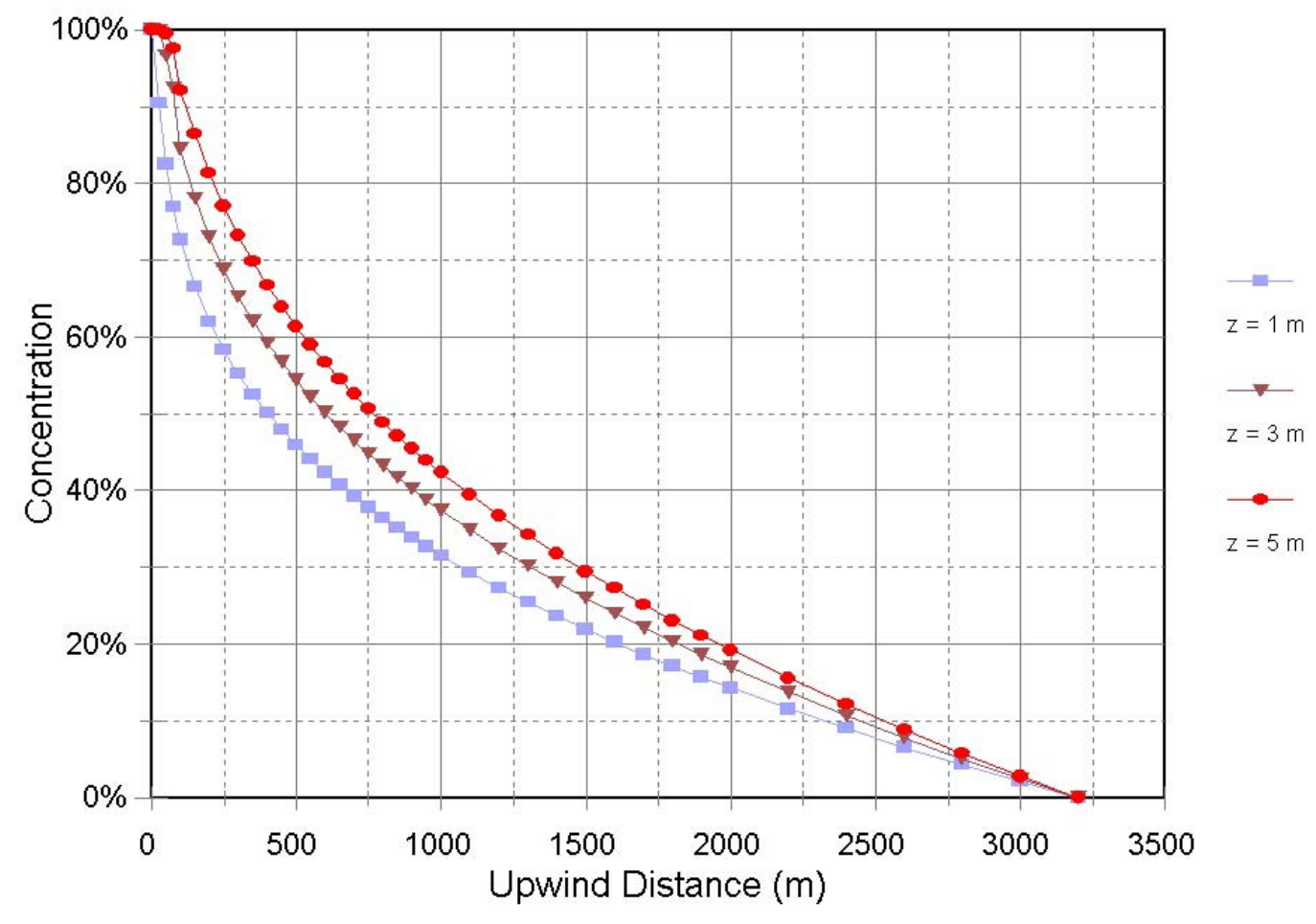

Figure 2. Reductions in dust concentrations as a function of distance upwind of the facilities in a northwesterly direction for three heights above ground.

It appears that soil stabilization from the facilities out to a northwesterly upwind distance of about $400 \mathrm{~m}$ to $800 \mathrm{~m}(1 / 4$ to $1 / 2 \mathrm{mi})$, depending on air intake height at the facilities, could reduce air concentrations by a factor of 2 . Soil stabilization from the facilities to an upwind distance of about $1200 \mathrm{~m}$ to $1600 \mathrm{~m} \mathrm{(3/4} \mathrm{to} 1 \mathrm{mi}$ ), again depending on air intake height, could reduce concentrations by a factor of 4 . Soil stabilization from the facilities to an upwind distance of about $2250 \mathrm{~m}$ to $2500 \mathrm{~m}$ (1.4 to $1.6 \mathrm{mi})$ could reduce concentrations by a factor of 10 . 


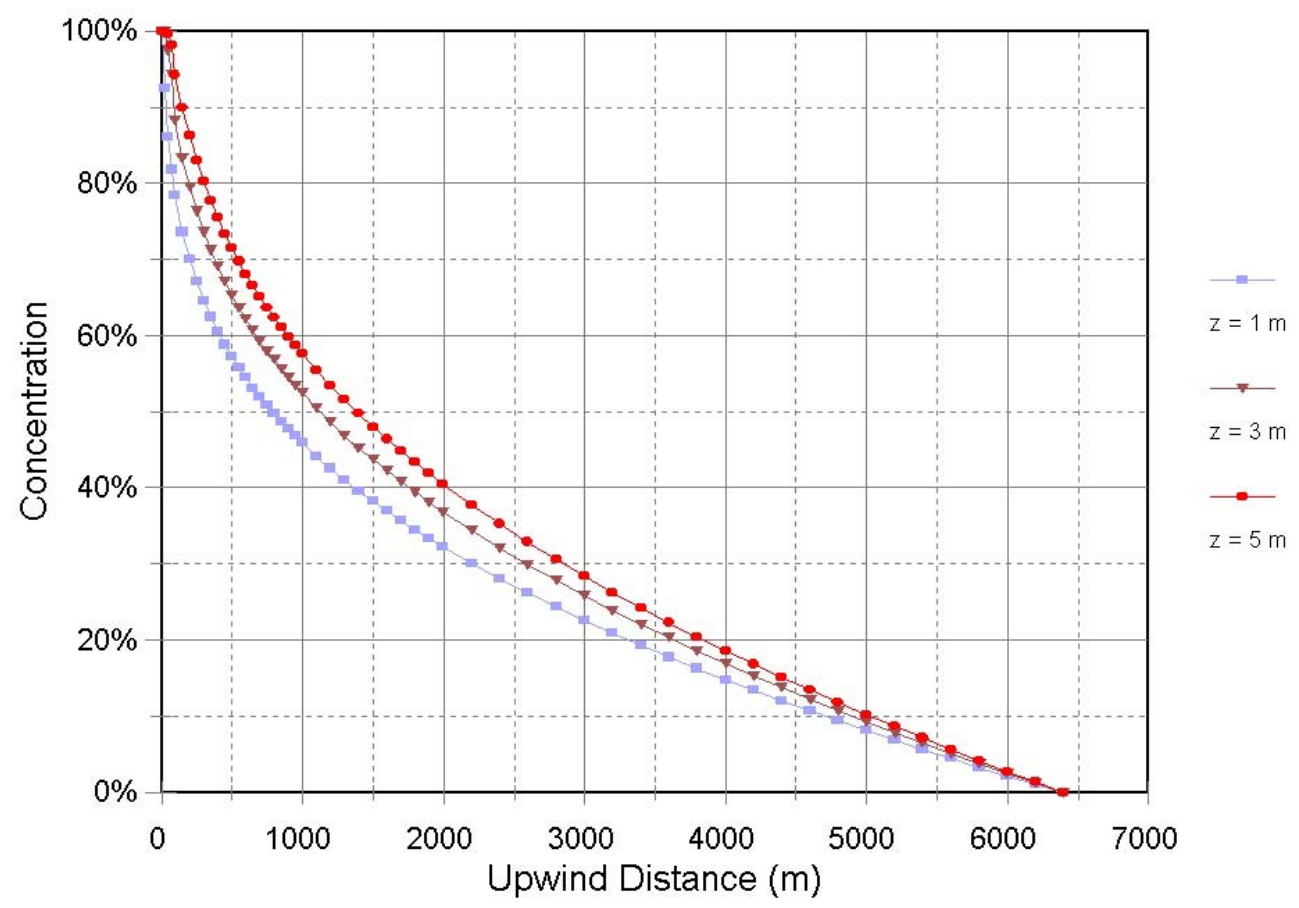

Figure 3. Reductions in dust concentrations as a function of distance upwind of the facilities in the southwesterly direction for three heights above ground.

It appears that soil stabilization from the facilities out to a southwesterly upwind distance of about $750 \mathrm{~m}$ to $1400 \mathrm{~m}$, depending on air intake height at the facilities, could reduce air concentrations by a factor of 2. Soil stabilization from the facilities to an upwind distance of about $2750 \mathrm{~m}$ to $3400 \mathrm{~m}$, again depending on air intake height, could reduce concentrations by a factor of 4 . Soil stabilization from the facilities to an upwind distance of about $4600 \mathrm{~m}$ to $5000 \mathrm{~m}$ could reduce concentrations by a factor of $\underline{10 .}$

It should be noted, in light of Figures 2 and 3, why soil stabilization near the facilities instead of at the furthest point upwind would be most effective. Dust generated from the source area located furthest upwind of the facilities has the opportunity to diffuse (resulting in reduced concentrations) more than dust generated closer to the facilities. Consequently, the preponderance of the dust experienced at the facilities comes from the eastern portion of the source area, i.e., proximal to the facilities. Also, the southwesterly source area likely contributes roughly $25 \%$ more airborne dust at the receptor location than the northwesterly source area.

It should also be noted that stabilization of only a portion, however large, of the source area might not ultimately yield the corresponding reductions in dust concentrations presented in Figures 2 and 3. This may particularly be the case with the passage of time following stabilization. Treated soils may be bombarded by heavy particulates (saltating 
sand, etc.) from the adjacent untreated portion, which may destabilize treated soils, turning them back into a source of fugitive dust. It is therefore advisable to apply soil fixative to the entire source area, if possible.

\section{Long-Term Stabilization of the Entire Source Area (Fall 2001)}

Although grass seed could be applied with the soil fixative in spring 2001, long-term stabilization of the source area via establishment of grasses is not advisable at this point in the growing season. Grass seed applied with the soil fixative in spring could imbibe sufficient water from the water-fixative slurry, or from a summer rainstorm, to trigger germination. Once germinated, seedlings would not survive due to lack of water during summer. Consequently, establishment of grasses should begin just after the onset of fall rains and cooler temperatures, e.g., late October.

We recommend seeding only native species in the source area. One possible seed mixture, for which seeding costs have been evaluated (Wildlands, Inc.), is presented in Table 2. A quantity of Hanford-derived seed, sufficient to plant the entire 6,000-acre source area, is not available. The source of the seed that would be used to plant the source area is a grower in Eltopia, WA. The grower has indicated that demand for seed for fall plantings, particularly by the U.S. Bureau of Land Management, is expected to still be very high (as a result of last year's fires and in anticipation of another potentially severe fire season this year) and that orders are normally placed in the spring. Consequently, availability of seed may be short lived. Therefore, an order should be placed within the next week to two weeks, in order to secure the quantity of seed that would be needed for this project.

Table 2. Possible seed mixture for the 6,000-acre source area.

\begin{tabular}{|c|c|c|}
\hline Common Name & Latin Name & $\begin{array}{c}\text { Pounds of Pure Live } \\
\text { Seed }^{\text {a }} / \text { Acre }\end{array}$ \\
\hline Indian rice grass & Oryzopsis hymenoides & 2.0 \\
\hline Needle-and-thread grass & Stipa comata & 0.5 \\
\hline Sand dropseed & Sporobolus cryptandrus & 1.0 \\
\hline Sandberg's bluegrass & Poa sandbergii & 2.0 \\
\hline Sherman big blue grass & Poa secunda & 4.0 \\
\hline Total $^{\mathrm{b}}$ & & 9.5 \\
\hline
\end{tabular}

${ }^{a}$ Pure live seed consists of viable seed and excludes noxious weeds, impurities, etc. The number of pounds required varies by species depending on the size of individual seeds, i.e., species with smaller seeds require fewer pounds per acre to achieve the same coverage.

${ }^{\mathrm{b}}$ According to Wildlands, Inc., who obtained this information from the seed producer (located in Eltopia, WA), the normal seeding rate for these species (on a site such as the project area) is $\sim 6 \mathrm{lbs} / \mathrm{acre}$. This rate was increased $50 \%$ to account for harsh environmental conditions and thus help ensure success of the planting.

Several U.S. Bureau of Land Management (BLM) districts in northern Nevada and southern Utah have had native seed (used for fire restoration) treated with a fertilizer spray formulated (3-8-3 [N, P, K]) to promote seedling establishment and growth. The fertilizer spray, originally used to treat dry land grains, was developed by Soil Spray Aid, Inc., in Moses Lake, Washington. Soil Spray Aid, Inc. also deploys application of this 
fertilizer spray to large quantities of seed. The fertilizer spray does not form a coat but is absorbed by the seed and contains no hazardous materials. Soil Spray Aid, Inc. can either treat seed at the location of the seed supplier, or treat the seed after its arrival on the Hanford Site. Seed can be treated for $\$ 0.20 / \mathrm{lb}$, for a total of $\$ 11,400$, for the quantity of seed required (assuming $9.5 \mathrm{lbs} /$ acre [Table 2]) for the entire 6,000 acres. The BLM (Winnemucca, Nevada district) has qualitatively reported major improvements in the basal area (number of stems, important for soil stabilization) of Sherman big blue grass in the first growing season after application of this fertilizer.

Grasses would be seeded using two tractors and two range drills. Range drills are preferred over broadcast seeding. Drilling seed maximizes seed-to-soil contact, facilitating germination and establishment. Broadcasting leaves seed on the soil surface where they can more readily be blown away and/or devoured by birds, and thus generally requires a higher seeding rate to achieve a similar level of grass establishment as drill seeding. Seeding of the entire source area would cost, including seed, $\$ 97.43 /$ acre, for a total of $\$ 584,580$, and would require approximately 40 days to complete. Seeding would begin on the ALE Reserve and move northward and eastward. In this manner, previously seeded portions would not be disturbed. The seeding cost per acre would remain the same for the new source area of approximately 4,000 acres, for a total cost of $\$ 389,720$.

By the time grasses are seeded in the fall, the soil fixative applied in the spring may no longer be highly effective, and undoubtedly would be disturbed during seeding. Consequently, soil fixative should be re-applied when grasses are seeded. Soil fixative can be applied immediately following seeding by trucks with large balloon tires (fat-tired floaters) at the same cost as the original spring treatment (Table 1). The fat-tired floaters would minimally disturb the seeded area, i.e., not substantially alter the depth at which seeds have been drilled (important for germination and establishment). Without soil fixative, it is possible that drilled seed could be carried away by wind or be covered by blowing sand. These phenomena likely contributed to the failure of the grass seeding campaign of fall 2000. Applying a soil fixative would minimize this problem, while not hindering germination and establishment. Polyacrylimide soil fixatives have been shown to be neither beneficial nor detrimental to the growth of seeded grasses (Al-Rowaily and West 1992).

A less desirable substitute for soil fixative is crimped straw. Crimping straw over the entire source area following seeding would cost approximately $\$ 200.00 /$ acre, for a total of $\$ 1,200,000$ (applied at a rate of 1 to 2 tons/acre). It should be noted that crimping straw did not salvage the failed grass seeding campaign of fall 2000. We believe that it would be a much less effective measure for holding drilled seed in place than a soil fixative.

It should be noted that, depending on grass establishment during fall 2001 and winter 2002, soil fixative may need to be re-applied to the source area in spring 2002. 


\section{Evaluation of Aerosolized Water to Reduce Airborne Dust}

This section qualitatively evaluates the idea of using aerosolized water to reduce airborne dust by precipitating suspended particles at or near the perimeter of the facilities. This idea surfaced during our last meeting and, although it is not part of the source area treatment, is addressed here for expediency. Opinions regarding the precedent for and efficacy of this idea were solicited from several atmospheric scientists at Pacific Northwest National Laboratory. Not one of the scientists contacted had ever heard of such an idea being implemented at a scale larger than that of vehicles used for construction (misters attached to such vehicles to reduce dust). All were of the same opinion that this idea would not be very effective, primarily for the following three reasons.

First, it was hypothesized that relative humidity would have to be at least $90 \%$ to permit sufficient coalescing of water droplets on particulates such that these would precipitate out of suspension. This high relative humidity would likely be very difficult to achieve considering the very low relative humidity and high temperatures that typify summers on the Hanford Site.

Second, even if $90 \%$ relative humidity could be achieved, coalesced dust/water particles would still not readily precipitate in high wind events. In order to achieve settling, coalesced particles would have to be the size of raindrops. This would require layering a sufficient number of mist towers a sufficient distance upwind of the facilities in order to achieve precipitation upwind of the work environment.

Third, towers from which the water mist would be dispersed would only treat a portion of the dust plume due to the limited height to which they could be built. The untreated portion of the dust plume would still pass over the facilities and contribute some respirable and settled particles to the work environment.

\section{References}

Al-Rowaily, S. L. and N. E. West. 1992. Effects of Polyacrylimide on Establishment and Growth of Crested Wheatgrass Seedlings and Sagebrush Tubelings. Symposium on Ecology, Management, and Restoration of Intermountain Annual Rangelands, Boise, Idaho, May 18-22. Pages 275-280. 